1990

\title{
The Epistemology of Judging: Wittgenstein and Deliberative Practices
}

Thomas Morawetz

University of Connecticut School of Law

Follow this and additional works at: https://opencommons.uconn.edu/law_papers

Part of the Judges Commons, Jurisprudence Commons, Law and Philosophy Commons, and the $\underline{\text { Legal Education Commons }}$

\section{Recommended Citation}

Morawetz, Thomas, "The Epistemology of Judging: Wittgenstein and Deliberative Practices" (1990). Faculty Articles and Papers. 203. https://opencommons.uconn.edu/law_papers/203 


\section{HEINONLINE}

Citation: 3 Can. J. L. \& Jurisprudence 351990

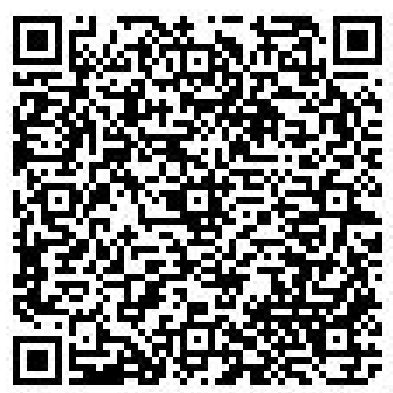

Content downloaded/printed from

HeinOnline (http://heinonline.org)

Mon Aug 15 18:14:32 2016

-- Your use of this HeinOnline PDF indicates your acceptance of HeinOnline's Terms and Conditions of the license agreement available at http://heinonline.org/HOL/License

-- The search text of this PDF is generated from uncorrected OCR text.

-- To obtain permission to use this article beyond the scope of your HeinOnline license, please use:

https://www.copyright.com/ccc/basicSearch.do?

\&operation $=$ go\&search $\mathrm{Type}=0$

\&lastSearch $=$ simple\&all=on\&titleOrStdNo=0841-8209 


\section{The Epistemology of Judging: Wittgenstein and Deliberative Practices}

\section{Thomas Morawetz}

\section{Introduction}

Wittgenstein seeks to inoculate us against the lure of metaphors.' The conundrums of philosophy are, he implies, often the misbegotten offspring of abused metaphors. How many rooms are needed to house the "fumiture of our mind"? With what key do others gain access to my "private" thoughts and feelings? ${ }^{2}$

Jurisprudence has its own syllabus of philosophical puzzles. One of the hardiest is the issue of judicial license and judicial standards. This issue has special fascination for American legal theorists because of the pivotal role played by the Supreme Court in exercising the power of judicial review by interpreting the Constitution. ${ }^{3}$ American theorists have taken for granted, and other theorists have seemed to acquiesce in this assumption,"s that to understand the nature of law is to understand how appellate judges find and/or make law. 6

An early version of this paper was prepared for the Seminar in Legal Philosophy, held at the University of Western Ontario in August 1989. I wish to thank the participants, and espectally Jules Coleman. Dennis Patterson, and Donald Regan, for their helpful comments.

1. L. Wittgenstein, Philosophical Investigations, G. Anscombe, trans., (New York: Masmillan, 1968). 3d ed., cf. Part I, section 115: "A picture held us captive. And we could not get outside il, for it lay in our language and language seemed to repeat it to us inexorably." and Part I, section 193: "The meshine as symbolizing its action: the action of a machine-I might say at first-seems to be there in 4 from the start. What does that mean?-If we know the machine, everything else, that is its movement. seems to be already completely determined."

2. Wittgenstein's own examples of abused metaphors are much richer and more layered. Consıder his observation about the metaphor of expression: "Misleading parallel: the expression of pain is a crythe expression of thought, a proposition.

As if the purpose of the proposition were to convey to one person how it is sith another, only, so to speak, in his thinking part and not in his stomach." (Philosophical Invesugultons, supra n. I. Pant I. section 317.)

Consider also the following: "One might also say: Surely the owner of the visual room would have to be the same kind of thing as it is; but he is not to be found in it, and there 15 no outstde." (Plulosophizal Investigations, supra n. 1, Part I, section 399.)

3. H.L.A. Hart remarks on this preoccupation and seeks to explan it in "Amercan Jurisprudence through English Eyes" in Essays in Jurisprudence and Philosophy (Oxford: Clarendon Press. 1983).

4. The work of Ronald Dworkin best illustrates this central preoceupation with the question of how judges find law as the key to the understanding of the concept of law. This postion was first sketehed in "The Model of Rules I and II" in Taking Rights Seriously (Cambndge: Havard Untv. Press. 1978). and remains the methodological basis of Dworkin's work in Las's Empure (Cambridge: Harvard Univ. Press, 1986).

5. In recent jurisprudence, the task of analyzing law is treated as the task of andyzang legal reasoning, and the main "official" reservoir of legal reasoning is judicial opinions. This was nor the case for sueh earlier jurisprudential theorists as John Austin and Hans Kelsen, for whom the anslysts of law was more or less the analysis of statutes. Thus, such British theorists as Neil Mlac Cormich give as much centrality to judicial reasoning as does any American theorist. On the other hand. Joseph Rax centinues in the older tradition that does not give precedence to judicial opinions over statutes as the mann resource for speculation about the nature of law. See N. MacCormick. Legal Reasoning and Legal Theon IOxford: Clarendon Press, 1978), and J. Raz. The Concept of a Legai System (Oxford: Clarendon Press, 1970).

6. Throughout this article, my references to judieial reasoning are tntended to charastenze appellate decisions. Even more restrictively. I am concerned langely with constututional interpretation at the appellate level. I am prepared to generalize my deseription of "deliberate praences" to judteral dectsion-making on a broader scale, but do not do so in this article.

Canadian Journal of Law and Jurisprudence Vol. III, No.2 (July 1990) 
Judicial review and the power of judges receive scrutiny periodically. The last fifteen years have been one such period, distinguished by a splendid outpouring of articles and books. ${ }^{7}$ Nonetheless, the issue remains largely unclarified notwithstanding the best efforts of inventive writers. Indeed, the most recent writings represent a scaling back of ambitions, in effect a tacit admission of failure. ${ }^{8}$

One Wittgensteinian explanation of such cycles in philosophy is that they involve the dogged pursuit of a metaphor. I shall argue that in the recent debates over constitutional interpretation the metaphor at issue has been the metaphor of a game, with its implications that judging is a rule-governed activity and judges are like the players of games.

In one respect this metaphor is special because it is the Wittgensteinian metaphor par excellence, the metaphor Wittgenstein himself is taken to have perpetrated. ${ }^{9}$ Many writers take as one of Wittgenstein's signal contributions to philosophy the suggestion that discourse is to be understood on the model of "language games". ${ }^{10}$ This suggestion is, as I shall argue, doubly misleading because Wittgenstein is not merely concerned with language and because his concern with discourse is not bounded by the metaphor of games." In examining the metaphor of games, therefore, I shall be considering its merits as a general metaphor for discourse, as a representation of what concerns Wittgenstein himself, and as a metaphor for legal discourse, specifically judicial interpretation.

The trajectory of the debates over constitutional interpretation in the last fifteen years is relatively clear. The concern in this round of the perennial

7. Any attempt to list the main contributors to this movement risks offending by omission--and any adequate list would be formidably long. Even a partial and inadequate list would have to include Paul Brest, Ronald Dworkin, John Hart Ely, Owen Fiss, Stanley Fish. Thomas Grey, Richard Kay. Sanford Levinson, Michael Perry, Jefferson Powell, Lawrence Tribe, and Mark Tushnet.

8. The main argument of Mark Tushnet's recent Red White and Blue (Cambridge, Mass: Harvard Univ. Press, 1988) is that all attempts to formulate a standard for constitutional interpretation on the basis of "grand theory" have self-destructed and they have done so because they are grounded on the untenable assumptions of liberalism. The recent work of Michael Perry (Morality Politics and Law (New York: Oxford Univ. Press, 1988)) and Sanford Levinson (Constitutional Faith (Princeton, N.J.: Princeton Univ. Press, 1988)) is not so much a frontal attempt to develop criteria for constitutional interpretation as an oblique investigation of the nuances and implications of the idea of constitutionalism.

9. The term "game" does double duty in Wittgenstein's Philosophical Investigations and in his other works. The use of the word "game" (Spiel) is itself an example of a "language-game" (Sprachspiel). Wittgenstein uses it to demonstrate that using language (participating in the "language-game") is not a matter of following rules, in particular not a matter of following rules that specify the necessary or sufficient conditions for using particular words correctly, not in other words a matter of understanding the "essence" of, e.g., a game. Compare Philosophical Investigations, supra n. 1, part 1, section 65: "For someone might object against me: 'You take the easy way out! You talk about all sorts of language-games, but have nowhere said what the essence of a language-game, and hence of language, is: what is common to all these activities, and what makes them into language or parts of language. ... And this is true.- Instead of producing something common to all that we call language, 1 am saying that these phenomena have no thing in common which makes us use the same word for all,- but that they are related to one another in many different ways."

10. Wittgenstein himself uses the term (Sprachspiel) frequently in Philosophical Investigations and elsewhere but, as $I$ argue below (text at n. 48), his own examples and questions (a) invite gencralization to non-linguistic practices and (b) reject unequivocally the paradigmatic use of any particular conception of a game.

11. It cannot be emphasized too strongly that I am not referring to Wittgenstein's awn use of the word "game" (Spiel) but to its use by those who see the essence of a game as a matter of acting in conformity with shared and mutually identifiable rules and sharing a conception of the point or goal to be achieved through participation. Wittgenstein argues persuasively against such essentialism; supra n. 9 and n. 48 below. Much post-Wittgensteinian philosophy, including contemporary jurisprudence, rests heavily on such essentialist assumptions. 
debate, as in previous rounds, ${ }^{12}$ is fear of judicial power and license. The first step in framing the issue is to note the failure of any purely formalistic account of decision-making. ${ }^{13}$ To say that judges apply law cannot mean that they do so deductively or by appeal to a straightforward algorithm. Hard cases arise, and hard cases are by definition ones in which both outcomes and methods of resolution are endlessly controversial. If this is so, what is the boundary of judicial power? If judges may choose among methods of resolution that are their own invention, is their power to remake law without limit? ${ }^{4}$

The second step is to meet the challenge of describing standards and techniques of judicial interpretation. The task is simultaneously descriptive and normative. A theorist claims to make explicit the techniques that are generally implicit in the process of judicial interpretation. ${ }^{15}$ But the theorist also claims thereby to be positing an ideal that is implicit in the role, an ideal that judges may or may not realize. The task is both hortatory and critical. The theorist speaks to judges in the hope of illuminating what they do and to critics of the judicial process in the hope of sharpening the critics' tools.

Implicit in the theorist's understanding of her task is the assumption that only one technique of interpretation is the correct way of proceeding, that only one set of rules characterizes judicial interpretation. To think otherwise, to concede that several acceptable techniques may coincide, is to readmit indeterminacy and license. If judges have the capacity to choose among several acceptable ways of proceeding, then the fear of license is well grounded and the critic is disarmed. The fear is not so much that anything goes in judicial interpretation, not that judges may appropriately consult astrological charts or their bias in favor of diminutive plaintiffs in making decisions. ${ }^{16}$ The fear is rather that within the range of defensible strategies, judges may effect and justify almost any outcome.

The third step, then, is to defend a particular strategy as the unique strategy that informs and constrains judicial interpretation. The theorist must argue first that the strategy is practicable, that it can in fact be carried out, and that it determines solutions to problems. ${ }^{17}$ The theorist must also argue that the

12. The trajectory of this phenomenon seems to have a twenty-five year or so cycle. Legal realism in the late 1920's and early 1930's revolutionized thinking about judicial decision-making. See L. Kalman. Legal Realism at Yale, 1927-1960 (Chapel Hill: Univ, of North Carolina Press, 1986). In the late 1950 's, the writings of Alexander Bickel and Herbert Wechsler, among others, marked another significant revival of interest.

13. The most influential critique of formalism in recent jurisprudence has been that of H. L. A. Hart. The Concept of Law (Oxford: Clarendon Press, 1961), chapter vii. An interesting recent example of the revival of formalism is E. Weinrib, "Legal Formality: On the Immanent Rationality of Law" (1988), 97 Yale L. J. 949.

14. The first half, chapters 1 through 5, of Tushnet, Red White and Blute. supra, n. 8, is a crituque of formalist and anti-formalist theories of judicial decision-making. (Tushnet uses the term "formalism" more broadly than I do here or than Weinrib does, see n. 13. Formalism. for Hart and Weinrib, characterizes decision-making by recourse to the "internal logic" of legal propositions. Formalism. for Tushnet, refers to any theoretical attempt to prescribe standards for decision-making.)

15. For a discussion of the claim that this is, as a general matter, the tasts of philosophy, see A. Danto. What Philosophy Is: A Guide to the Elements (London: Cambridge Univ. Press. 1968): R. Rorty. The Linguistic Turn (Chicago: Univ. of Chicago Press, ed. 1967), introduction.

16. There is an important distinction here between the factors that affect judieial dectsions and the reasons that are used by judges to justify opinions. Legal realism was concemed as much with the former as with the latter. The contemporary debate is primarily about the latter, about w has counts as justifieation in "official" judicial reasoning. The term "reasoning" is, of course, ambiguous, referring both to the process of discovery (or of arriving at an opinion) and the process of justification.

17. To say that a standard determines a result is not to say that a particular result follows deductively from 
strategy yields correct, or at least sound, answers.

This is not to say that all theorists share optimism about defining and defending a strategy of judicial interpretation. Counterpoised against such optimists are theorists who argue that the quest for a unique constraining strategy of judicial interpretation is doomed, and that the project itself is mired in contradiction. ${ }^{18}$

A diagnosis of the debate must begin with two observations. First, the very conception of the theoretical project is grounded on the metaphor of games. If we are to understand judges as constrained, we must understand the rules by which they must be playing. Such rules are both descriptive and normative. ${ }^{19}$ In the absence of such rules, judges must be seen as unconstrained.

By the same token, judges' attempts to justify favored outcomes by writing opinions makes sense if they are playing by the same rules. In other words, they must recognize reasons as relevant or irrelevant to decisions in the same way, must have the same methods for assigning weight to relevant reasons, and so forth. Unless this is so, unless they are playing the same game by the same rules, the process of justification in opinion writing is empty rhetoric. The task of the theorist, then, is to identify the rules of the game whereby judicial interpretation, and its explication in opinion writing, takes place-so that the true constraints of the process can be made explicit, so that correct decisions and techniques can be identified, and so that deviants can be chastised and corrected.

The second preliminary observation is that this account of the theoretical task seems wildly at odds with judicial practice, now and in any foreseeable future. The untheoretical observer's view is that judges do and will continue to decide cases in different ways. They will continue to write justificatory opinions in which they genuinely speak to each other but with different commitments about what is relevant and with little hope that, over time, diversity will turn into consensus.

From the point of view of the theorist, the situation is paradoxical. A player of chess plays with a player of Chinese checkers, and they in turn play with

the standard or that application of the standard dictates one particular result in a particular case. Analogously, the rules of a game like chess determine the course of play but allow for many possible different moves. They constrain and order the results but allow for a range of alternatives.

With regard to judicial reasoning, the adoption of a standard has two consequences. First, it mandates the kinds of reasons that can be given in justification of particular results. Second, in doing the former, it limits the range of results that may be reached.

18. As indicated above, this is largely the argument of the first part of Tushnet, Red White and Bltuc. See also other writers in the Critical Legal Studies movement, especially R. Unger, The Critical Legal Studies Movement (Cambridge, Mass.: Harvard Univ. Press, 1986), and D. Kennedy, "The Structure of Blackstone's Commentaries" (1979), 28 Buffalo L. R. 205. Owen Fiss labels the practitioners of critical legal studies "nihilists" and defends the label in "The Death of Law?" (1986), 72 Cornell L. R. 1.

19. The rules of many activities are both descriptive and normative. The rules of driving or swimming characterize the activity and are implicated in any description. At the same time, they also characterize a standard of performance. One can carry out the rules in a marginal or an exemplary way, without or with skill and expertise.

Two qualifications. (a) To say there are rules for driving or swimming is not to prejudge whether there is a single way to carry out the activity or many alternative ways. Indeed the meaningfulness of that question may depend on the level of generality at which the rules are posed.

(b) The rules of games such as chess and baseball are in part purely descriptive. The rule that a team in baseball retires after three players are "out" is hard to construe as normative, i.c. as a basis for evaluating better or worse games. 
a third who is playing bridge. Each justifies her moves by appealing to her particular game. And they persist. And yet they understand each other. How can this be so?

In Part 2 of this paper I shall examine the metaphor of games as a general philosophical strategy for analyzing discourse and human understanding. I shall look at some misapplications of the idea that the Wittgenstinian [author's preferred spelling, eds.] notion of a practice can best be understood as a "language game". I shall describe what I call "deliberative practices" to clarify the ways in which practices are not illuminated by the theoretical paradigm of a game.

Part 3 describes ways in which the metaphor of games gives a distorted view of judicial interpretation and it concludes that judicial interpretation is a paradigmatic case of a deliberative practice. Part 4 is a critique of the aims of recent theory about judicial, and particularly constitutional, interpretation insofar as the agenda of such theorists rests implicitly on the metaphor of games. My conclusion draws more general lessons for philosophical method in legal theory.

\section{Games and Practices}

\section{a. Wittgenstein and Practices}

The concept of a practice is at once among the most useful and most disputed tools of twentieth-century philosophy..$^{30}$ Many philosophers trace their use of it to Wittgenstein, and the Wittgenstinian concept, as a philosophical tool, is often assimilated to that of a "language game". After explaining the concept in Wittgenstein, I shall argue that, used in a certain way, the notion of a language game is doubly misleading.

An intuitive look at practices may begin with such nonlinguistic activities as driving or swimming. In each case, persons acquire skills or ways of proceeding that become habitual and unreflective. When we call such skills "second nature", we mean that, though they are socially and culturally acquired, such ways of proceeding become as much a part of us as our genetic endowment.

A habitual repertoire has distinctive features. Each technique involves ways of perceiving, feeling, and acting. A good driver makes judgments about road conditions and the disposition of other drivers, apprehends dangers, and acts accordingly. What she does unreflectingly can, however, be made conscious. Ordinarily the need to do so will not arise."I

20. Philosophers who have discussed Wittgenstein's use of the concept most Illuminatungly are P. Hacker. Insight and Illusion (Oxford: Clarendon Press, 1972), S. Kriple. Wittgenstem on Rules und Pru ute Language (Oxford: Basil Blackwell, 1982). S. Hilmy, The Later I'utgenstem (Oxford: Basil Blaskwell, 1987), and R. Rorty, Philosoply and the Mirror of Noture (Pnnceton. N.J.: Princeton Univ. Press. 1979). The implications of the notion of a practice, and of the concomitant distinetuon between being inside and outside a practice, go far beyond the realm of Wittgenstein studies and are explored in contemporary philosophical movements from hermeneuties to neo-Kantianism and neo-Hegelianusm. See, for example, H-G. Gadamer, Truth and Method. G. Baden and J. Cumming trans. INew York: Continuum, 1975) and Hegel's Dialectic (New Haven: Yale Univ. Press, 1976). Hoy. The Cruncal Circle (Berkeley: Univ. of California Press, 1978). G. Shapiro and A. Sica, Hermeneutics Questions and Prospects (Amherst: Univ. of Mass Press, 1984), and R. Geuss, The Idea of a Critical Theary (Cambridge: Cambridge Univ. Press, 1981).

21. The need to do so will arise if one is instructing someone else or if one has to releam the actrity after. for example, an injury. 
A characterization of what is involved in having such a skill, in being a good driver, will be at once descriptive and normative. The characteristics of a driver (in general) are distinguished only in degree from the characteristics of a good driver. To be able to identify driving is also to be able to detect good driving. Both thresholds are inherently vague. No clear and simple criterion distinguishes those who cannot drive from those who do so very badly. Similarly, not everyone will agree on the marks of very good driving. But the range of understandable disagreement is small..$^{22}$

Some of our practices are primarily communicative (as driving obviously is not). And some of our communicative practices, by far the most important ones, are linguistic. ${ }^{23}$ Wittgenstein attends to such aspects of language as color-descriptions and expressions of pain. Just as driving is a skill that individuals acquire because a public practice, a shared activity, already exists, so too perceptions of color and distinctions among kinds of pain manifest the acquired skills of those who have been initiated into certain practices. Persons identify colors and pains to the extent that a place exists for the recognition of color and the expression of pain in the relevant practices of a culture. ${ }^{24}$

Some philosophers have seen this suggestion as revolutionary and counterintuitive. The philosophical assumption of most empiricists has been that the domain of private experience is fully configured and that the public arena of language is merely a set of conventions and labels attached to the distinct elements of private experience. ${ }^{25}$ But Wittgenstein challenges this. He asks us to reflect on what it could be like to experience a color for which a place was not already prepared in the experiential realm shared with others. ${ }^{26}$

\section{b. Deliberative Practices}

These considerations about practices in general and about simple linguistic practices have implications for more complex practices that involve deliberation. I shall explain the ways in which deliberation about, say, judicial

22. This means merely that one can anticipate the range of variation in criteria for driving-and one can anticipate the kinds of criteria that simply make no sense (unless an exceptional context is created). One person may tend to favor careful drivers who obey speed limits, while another may favor accident avoidance even at excessive speed. But it would be hard to understand "crashing into as many red cars as possible" as a standard for good driving (unless the act is part of a contest, etc.).

23. Non-linguistic ones are waving and pointing. See Wittgenstein, Philosophical Investigations, supra, $\mathrm{n}$. 1 , part I, section 454 .

24. In Philosophical Investigations, supra $\mathrm{n}$. 1, Wittgenstein discusses color in Part 1 , sections 273 through 278. Consider, for example, section 275:

Look at the blue of the sky and say to yourself "How blue the sky is!"-When you do it spontaneously - without philosophical intentions-the idea never crosses your mind that this impression of colour belongs only to you....

See also Wittgenstein, Remarks on Colour, L.L. McAlister trans. (Oxford: Basil Blackwell, 1977).

Wittgenstein's extensive discussion of pain in Philosophical Investigations is to be found in Part I at sections 283 to 304,310 to 317,350 to 351,384 , and 391 through 398 . Consider section 384: "You learned the concept "pain' when you learned language."

25. In the history of British empiricism, John Locke held a distinctive theory along these lines. See An Essay on Human Understanding (Oxford: Clarendon Press, 1894). In the twentieth century. Bertrand Russell and A. J. Ayer clung to many of the traditional tenets of British empiricism.

26. Philosophical Investigations, supra n. 1, Part I, section 381: How do I know that this colour is red?It would be an answer to say, "I have learnt English."

Two qualifications are relevant. (a) An individual may experience colors that have no simple name. One may say that one wants "a slightly pinkish shade of pale ochre" on one's wall. But the color one envisions is a color that one imagines others capable of envisioning. (b) The communal color language may change over time. Words like "indigo" and "cerise" may fall in and out of ordinary use. 
decisions is more complex than deliberation about color or pain.

All practices allow the possibility, indeed the inevitability, of idiosyncracy within shared ways of proceeding. Even if it is true that persons have a shared conception of the nature of driving, each driver also has a personal style. Even good drivers differ in style. Each of us has a distinctive way of using color language. I may tend not to discriminate among various shades of red; a friend may tend to distinguish sharply between scarlet and crimson; another friend may use these two terms in a distinctively different way from the first friend. ${ }^{27}$

In deliberative activities this possibility of diversity within shared, and mutually understood, ways of proceeding is especially significant. A deliberative practice involves discourse with the shared purpose of forming and defending judgments. Examples of deliberative practices are esthetic debate, moral reasoning, historical discourse, and judicial decision-making. The subject may be the beauty of an object, or whether an action is right, or whether an event is a turning point in history, or whether a plaintiff has a right to a favorable judgment. All such debates have certain features in common. All refer to widely shared activities and/or institutions in civilized societies. All are realms of discourse that seem almost indispensable in the transactions of civilized persons. In all these domains, the main debates extend over the history of civilization and seem intractable. ${ }^{28}$

It is equally important to see what draws participants together as to see what separates them. ${ }^{29}$ Even when they disagree, they recognize the argumentative strategies of others. They share a sense of what reasons are relevant to the common discourse. Discussing beauty, they may consider symmetry and asymmetry, balance and imbalance, representational aspects of the object, context, purpose. They will not consider relevant whether the artist had long or short life, whether her name began with a vowel or consonant, or whether the object or performance is privately or publicly financed. These observations may seem trivial, but only because they are so familiar, so much a part of what we do. They are "second nature". Each participant can anticipate ${ }^{10}$ the moves that others will make. The practice consists in the recognition of a family of reasoning strategies that admit a spectrum of judgments.

But it is not the case that anything counts. To say that any move is permissible is to say that no move is permissible. Just as in driving or in identifying colors, the publicly shared understanding of what moves are

27. It is important that the question which of the three of us is correct in hus use of color terms may be a meaningless question. All three ways of speaking may be appropraste in different contexts and there may be no general criteria, relevant to all contexts, for distingusshing searlet from enmson. When and where they are needed, new conventions will be invented.

28. This point is true whether one is speaking of individuals, and saying that these subjects have conserted persons in all cultures and been richly debated over the course of hustory, or speaking of so-called schools of thought, and saying that distinctive points of view about these issues lobjeclivism v 3 . sub. jectivism, realism vs. idealism, relativism vs. absolutism) have reeurred insistently over the history of human speculation.

29. For an extended discussion of this point see T. Morawetz. Wirtgenstem und Kinonsedge. The Importance of On Certainty (Amherst: Univ. of Mass. Press, 1978).

30. That is to say, one can anticipate a range of intelligible moves and responses. If a response is sholly unexpected and seems unintelligible or nonsensical, one can construct the kinds of conversational bridges that would make it intelligible. Of course, conversations sometimes take surprising tums within the bounds of these constraints. 
comprehensible ways of proceeding is what makes the practice possible.

If participants are able to discuss beauty, justice, and historical influence because they have learned what is relevant to such discourse, how is it that they do not all act the same, all reaching the same conclusions in the same way? In simpler practices, color identification for example, differences among individuals are usually treated as de minimis. In general, it is neither of philosophical nor practical interest to argue at length over whether a color sample is really midnight blue or indigo. This is another way of saying that color language is not really a deliberative practice.

Deliberative practices are characterized both by what binds participants together and what distinguishes them. No two persons have had the same history or the same characteristics. Some are more credulous than others, more perceptive, more doubtful, more hesitant. Much more importantly, each will have a characteristic way of reasoning that cuts across the several deliberative practices in which she participates and represents an interpretive orientation to the world, a way of sorting out the phenomena of experience and making sense of them.

This needs explanation. I shall first look at examples drawn from deliberative practices other than legal reasoning. In section 3,1 shall look at judicial interpretation directly.

Consider first debates about beauty. How diverse may be the reasons given to justify and explain esthetic judgments? What kinds of different strategies may participants in the practice expect to meet? One person may offer psychological grounds for attributing beauty. Another may refer to inherent properties of the object itself. Yet another may look to the ways in which the object expresses the intentions of the artist, and/or the quality of those intentions. A fourth may appeal to the social and political role of the object as a basis for esthetic merit. ${ }^{31}$

A debate among such participants is complicated even further by the fact that these several strategies of reasoning are not independent of each other. Each participant will to some extent take account of the reasons offered by others by finding a place for them within her own favored strategy.32 One may explain psychological response as a manifestation of inherent features of the object, while another may say that accounts of inherent features are reducible to psychological factors. Thus, a part of each participant's way of proceeding will be a strategy for incorporating or dismissing the favored strategies of others. And each in turn will recognize and anticipate such moves as part of the ongoing practice. ${ }^{33}$

Two observations. The diverse strategies that make up a deliberative practice compete insofar as there is no natural order of precedence among cate-

31. An anthology of historical approaches is A. Hofstadter and R. Kuhns, Philosophies of Art and Bcauty (New York: Modern Library, 1964). A collection of recent diverse writings is C. Harrison and $\vec{F}$. Orton, Modernism, Criticism, Realism (San Francisco: Harper and Row, 1984).

32. By using the word "strategy" for what others may call (and for what I call elsewhere) a "way of proceeding" and "way of reasoning", I do not imply that these strategies serve ulterior aims or that they involve strategic planning.

33. Compare Philosophical Investigations, supra, n. 1, Part 1, section 241: "'So you are saying that human agreement decides what is true and what is false?'-It is what human beings say that is true and false; and they agree in the language they use. That is not agreement in opinions but in form of life." 
gories of facts, among categories of reasons and justifications. For example, psychological explanations are not inherently more basic than political and economic explanations, nor is the reverse true. Appeals to the inherent features of a work of art are neither more nor less basic a mode of justification (in esthetic reasoning) than appeals to the creator's intentions. ${ }^{-4}$ In defending one's own judgment in a particular case, one is also defending one's style of judgment, one's way of ordering the data of experience to give some kinds precedence. The attempt to convince others is not only an attempt to make them agree with one's own conclusions but also to bring them around to deploying reasons in the same way. ${ }^{3.5}$

The second observation is that the persuasive attempts of each participant are not, as one might think, doomed. ${ }^{36}$ To say that each participant has a particular way of proceeding in reasoning is not to say that he is condemned to repeat the same moves forever. Individual participants differ not only in judgments and in ways of reaching those judgments, but also in their susceptibility to persuasion, to considering and adopting other points of view and other strategies. Similarly, the practice itself, as a collection of strategies mutually recognized by participants, evolves. In retrospect ${ }^{37}$ a theorist finds that some strategies gain currency while others go into temporary or permanent eclipse. ${ }^{38}$

Other deliberative practices can be analyzed similarly. One historian will use the influence of ideas as the explanans that unlocks historical change, another will look to economic motives and events, while still another will stress the charismatic influence of leaders. ${ }^{39}$ In moral discourse, some theorists will see altruistic utilitarianism as offering the most coherent account of reasons relevant to moral judgment, another will see psychologistic or hedonistic utilitarianism as basic, while another will say that moral reasoning is essentially deontological..$^{40}$

34. Reductionism was more widely discussed in the philosophy of selence and of soetal setente a genseation ago that it is today. Compare E. Nagel. The Structure of Staente (New York: Hareourt and Bruce, 1961) with H. Brown. Perception, Theory and Commument (New York: Columbis Unv. Press. 1979).

35. This fact, I would argue, is what fuels debate within deliberative practuces. Particupants mantfest and seek to validate their ways of thinking through participation. (This is a truism rather than a claum for empirical psychology.)

36. Wittgenstein is sometimes falsely charged with conservatism. The suggesuon is that innovation and change are ruled out by a practice-based account of expenence because individuals can only leam and do what others have done before them. This shows a misunderstanding of Wittgenstem and of preetices. Part of what one learns in acquiring a practice is the constraints withn wheh creatis thy and innovation are possible. See relevant discussion in D. Pole. The Later Philosophy of Wiusenstein tLondon* Athlone Press, 1958) and D. Bloor. Wittgenstem: A Soctal Theory of Knowledge (New York: Columbia Univ. Press, 1983), at pp. 160-173.

37. Hegel's familiar reference to the owl of Minerva implies that shifts in collectuve way s of thinking can only be appreciated and understood retrospectively. See G. Hegel. The Philosophs of Righti, Knox trans. (Oxford: Clarendon Press, 1942). preface: "The owl of Minerva spreads us wings only is th the falling of the Dusk." Thomas Kuhn's innovative work on scientifie revolutions has the same implication. The nature and significance of a scientific revolution can only be appreesated after it has oscurred and after a new way of thinking has came to inhabit "normal seience". See below at $n .67$.

Arguably, certain political and esthetic manifestoes are self-eonseious attempts to alter prevaling practices. They are Janus-faced. Their contemporaneous intelligibility depends on thetr relationship to existing practices but they are prospective attempts to transform those very prostices. Constder for example the esthetic manifestoes of Kandinsky, Apollinaire, Mondrian, and the futurists.

38. Examples in politics are the hierarchic presuppositions of feudalism and of Renaissance statecraft.

39. These ways of looking at history are attributable, respectively, to Max Weber. Frnedrich Engels, and Thomas Carlisle (and their followers).

40. The philosophers most closely identified with these positions are, respectuvely, John Stuart Mill. 


\section{c. On Language Games}

Wittgenstein does not give an account of deliberative practices. His examples of practices are simpler: discourse about color, communicative expressions of pain, and so on. ${ }^{41}$ Nonetheless, certain themes of his account of knowledge, certainty and judgment seem fundamental to any general account of discourse. An individual's ways of reasoning and understanding, and arguing and judging, are spontaneous ways of organizing experience that reflect a shared practice. Reasoning and understanding are parts of a learned repertoire as much as are swimming and driving. Every practice is as simple and as complicated as it needs to be to serve as a tool for organizing experience and proceeding through it. If we have not invented a sharp distinction between crimson and scarlet, the reason is that we do not ordinarily need it. If we operate with different but related strategies in reaching legal decisions as judges, then an account of the practice must recognize and respect the diversity and relatedness of those strategies. Philosophy, Wittgenstein tells us, leaves everything as it is. ${ }^{42}$

The term "language game" is doubly misleading. The analogy of driving and swimming demonstrates that some practices are non-linguistic. Practices that $d o$ involve language are not exclusively linguistic. Necessarily, the experiences and expectations of color identification presuppose that there are linguistic conventions through which we have been taught and by which we communicate. But the skill of color recognition is no more reducible to skill in using words like "yellow" than the skills of driving are reducible to the skill of using terms like "stop" and "accelerate".

The same goes for deliberative practices. The patterns of reasoning involved in forming and justifying judgments are patterns expressed in language and described through language. But the intellectual strategy that leads someone to explain social and economic phenomena by reducing them to patterns of individual psychology is not adequately described by rules that instruct one in the use of words. ${ }^{43}$ By focusing on the idea that practices are made up of shared linguistic rules, some followers of Wittgenstein imply that on-going practices are more homogeneous than they really are..$^{44}$ It is important to remember how diverse are the variant strategies of historians, or moralists, or judges that are expressed in the same shared lexicon.

Just as deliberative practices are not, or not merely or primarily, activities of language, so too they are not very much like games. Some similarities are obvious and explain the seductiveness of the metaphor. One must be initiated

Thomas Hobbes, and Immanuel Kant. Each has influenced ethical theorists through subsequent generations. In my references to ethical theory $I$ am assuming that the positions of various theories bridge questions of metaethics and questions of normative ethics. In other words, theorists reach what John Rawls calls "reflective equilibrium" with regard to reconciling metaethical commitments and substantive ethical judgments. See Rawls, A Theory of Justice (Cambridge: Harvard Univ. Press, 1971), at 20.

41. Supra, nn. 26 and 27.

42. Philosophical Investigations,supra n. 1, Part I, section 124. "Philosophy may in no way interfere with the actual use of language; it can in the end only describe it.

For it cannot give it any foundation either.

It leaves everything as it is."

43. See I. Hacking, Why Does Language Matter to Philosophy? (Cambridge: Cambridge Univ. Press, 1975), chapters 11-13.

44. See articles in S. Holtzman and C. Leich, Wittgenstein: To Follow a Rule (London: Routledge and Kegan Paul, 1981). 
through a period of learning. Once one has become a participant, one can make appropriate or correct moves and one can make mistakes. ${ }^{\text {s5 }}$ As in games, ${ }^{46}$ some rules are constitutive rather than regulative. This means that a participant gains a new way of looking at a domain of experience that is constituted by the concepts and conceptual relationships she has learned. For example, thinking and talking about strikes and runs is meaningless outside the domain of baseball. To leam the rules of baseball is to enter a new domain of experience. Similarly, to learn the concept of a tort or a privacy right is not merely to acquire a new way of thinking about the world; the experienced world itself acquires new characteristics. The idea of a tort only belongs in a world governed by law. 47

Practices are not games. Games have beginnings and ends. Usually they proceed by discrete moves, rounds, or turns. Games ${ }^{\text {th }}$ are at bottom reducible to rules and all players must play by the same rules. Moreover, some of the rules must specify the point of playing, the goal that gives purpose to the players' moves. Players may differ in strategy and technique but there is ordinarily a clear distinction between the rules, on which they must agree, and the strategies of play, on which they may well differ."

In characterizing a relatively simple linguistic practice, such as color language or pain language, the game analogy is compelling. It makes sense to say that in identifying shades of blue or describing aches, a condition of the recognition of and communication about such experiences is that participants follow the same rules. ${ }^{50}$ Either they follow the same rules and are participants in a shared practice, or they do not and the scope of their color and pain experience remains inaccessible and uncertain."1 But even in these prac-

45. See Wittgenstein, On Certainty (Oxford: Basil Blachwell, 1969), sectun o14

46. J. Rawls, "Two Concepts of Rules". (1955) 64 Philosuphicul Revers 3.

47. The distinction between constitutive and regulatuve rules land between consthtuture and desnotue concepts) has unclear borders. Consider. for example, the economist's use of the $t \mathrm{tm}$ "preference salisfaction." The term has technical significance in economse theon but also refers to a phenomenen thas lives outside the domain of economic theory. The same can be said of the sostologist" use of the term "charisma." The same. however, cannot be said of "run" or "strike" in bastball.

48. Wittgenstein, as noted above at $n$. 9. admonishes us to remember that if we "loos and sate whether there is anything common to all" games, we "will not see something that w common to all, but similantte. relationships, and a whole series of them at that." He goes on. "I ean thunh of no belter erpressson to characterize these similarities than "famly resemblanees": for the brous resemblantes batseen members of a family: build, features, colour of eyes, gail, temperament, ete., ets, urerlap and ensi-cross

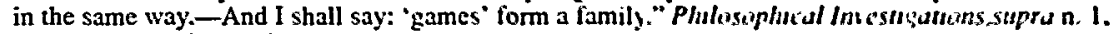
Part I, sections 66 and 67 .

My critique is of the use of a paradigm of games whereby all participants follow the same rules and have in mind the same point or purpose for engaging in the joint attivity Raw is and kuhn uwe the paradigm to illuminate political and scientific activity.

49. In actual games and in the game-paradigm. the distinction is mantaned between rules, by which all players must abide, and strategies, which players may devise on therr own and wheh are likely to differ from player to player. It is relatively easy to son out the aeturues of baseball players or chess play. ers along these lines.

The use of the game-paradigm for judges presupposes that in judgung as well one can disungush the rules from strategies. One of my main criticisms of the use of the metsphor of games for daliberatue practices is that this distinction cannot be made in the case of judging. In other sords, the yuest for shared rules of relevance for justificatory reasons must yield to the recognituon of a pluraluty of competing strategies of justification.

50. This is not to say that Robinson Crusoe, alone on a desert island. cannot noute a parucular color of fruit and then reidentify the color elsewhere on the island. But terms that he invents and uses are in principle terms that he can share with any subsequent vistors to the island: in principle his language can be a public language. The "private language" question is much debalted in uritungs on Wittgenstein. See, for example, Kripke, supra n. 20.

51. Compare Philosophical Investigations, supra n. I, Part I, section 250: "W'hy can't a dog simulate 
tices, the game analogy breaks down. For one thing, the rules of the practice are not constitutive of pain experience in the same way that the rules of chess are constitutive of the experience of castling and checkmating. For another, color and pain recognition does not proceed in goal-directed moves.

The game metaphor breaks down altogether in accounting for deliberative practices. A basic constraint of the metaphor is that justificatory arguments make sense only among participants who are playing by the same rules, who have the same standards of relevance for reasons. Among persons playing by different rules, justificatory moves are mere illusions and discourse proceeds at cross-purposes. Understanding this, participants must abandon their attempts or coerce (rather than persuade) others into playing by their rules. .52

But in deliberative practices justificatory moves proceed in the face of differing strategies of reasoning. The practice consists in the recognition that these differing strategies exist and compete. From the standpoint of games, this characteristic of deliberative practices can only be a paradox. On discovering that others are playing by different rules, one will either bring them around to playing by the same rules or stop playing. Making further moves loses its point when others are playing a different game. The game itself loses its point.

And yet, the very point of deliberative practices seems to be to justify both a particular result and a particular way of reaching the result against those who reason differently. Participants have a stake not in a particular set of arbitrary rules but in a particular way of making sense of experience. A deliberative practice is a domain within which such different strategies compete. To give up or alter one's method of justification is not simply to decide to play by different rules but to decide to see the world differently.

Rather than saying that we can understand deliberative practices by seeing them as a kind of game, we might say rather that we can understand games as simplified, externalized, and therefore degenerate kinds of practices. ${ }^{53} \mathrm{~A}$ justificatory response within a game ("Why did you move as you did?") may be a reminder of the shared rule or a reference to the player's strategy for winning..$^{54}$ The rules are fixed, arbitrary, and assumed to be known to all. But only the least important aspects of experience have this kind of simplicity. Only the least important aspects of life leave participants the option whether or not to play. In the more immediate and important practices-moral practices, psychological transactions, economic and professional judgments-we have

pain? Is he too honest? Could one teach a dog to simulate pain? Perhaps it is possible to teach him to howl on particular occasions as if he were in pain, even when he is not. But the surroundings which are necessary for this behaviour to be real simulation are missing."

52. In On Certainty, Wittgenstein says, in confronting those who reason differently, "we use our language-game to combat theirs," section 609 . According to this assumption, reasoning and persuasion and justification are possible only among those who reason in the same way; otherwise, there is only competition and combat.

53. True games can be seen as mimicking the ordered or practice-like character of all conduct but in a form in which the goal is arbitrarily posited (and therefore bears no inherent relationship to human needs and desires) and in which moves and rules are simplified into relatively simple and rigid patterns.

54. See stupra $n$. 49. for discussion of the distinction between rules and strategy in the context of a gameand for an argument that the distinction evaporates in a deliberative practice. 
a stake unavoidably and the shared rules-and-strategies are endlessly controversial.

This conclusion about deliberative practices has implications for the role of theorists. Games afford a clear distinction between players and observers, insiders and outsiders. ${ }^{55}$ Insiders play by the rules and justify their actions by resort to the rules. Outsiders are not bound by the rules. As observers, their questions about justification involve the justification of one set of rules in comparison with other variants of the game.

In considering deliberative practices, we lose the sharpness of this distinction. In part, the distinction remains in place. Practitioners inhabit a particular strategy of moral argument, historical interpretation, and so on, while theorists are occupied in noting and describing variant strategies. But part of one's understanding of deliberative practices as a theorist involves an interpretation, necessarily controversial, of the point of the exercise-of the point of esthetic activity, moral criticism, historical investigation. A theorist as well as a practitioner will therefore have a stake in a particular strategy and an attitude toward the point of the practice. This will color her account of the practice. A justification of the practice from a theoretical standpoint will look much like a justification given by a practitioner with a particular strategy within the practice. ${ }^{56}$

\section{Legal Interpretation as a Deliberative Practice}

\section{a. Judges and Games}

In this section I shall consider why the metaphor of games is a seductive tool for understanding constitutional interpretation, ${ }^{57}$ why this metaphor can be said to confuse the analysis, and how the suggestion that judging is a deliberative practice, rather than a game, satisfactorily explains what judges do.

Three decades ago, political and legal philosophy in England and America were reborn. ${ }^{58} \mathrm{~A}$ crucial ingredient of this renaissance was the idea that political and legal reasoning constitute practices and that the job of theorists is to

55. One of the most widely discussed aspects of Hart's jurisprudential su ntings is his distinction betw een an internal and an external point of view. This distinction has also oceupied moral philosophy over the last forty years. See Hart, n. 13 supro. at 55-60; P. Soper. A Theon of Luy (Cambndge, Mass: Harvard Univ. Press, 1984); K. Baier, The Moral Point of liew' (Ithaca: Comell Univ. Press, 1958 I: B. Williams. Ethics and the Limits of Philosophy (Cambridge Mass: Harvard Univ. Press, 1985): and T. Nagel. The View from Nowhere (New York: Oxford Univ. Press, 1986).

56. Whether one is concerned with practitioners such as the justices of the U. S. Supreme Coun or w ith theorists such as Tushnet, Ely. Bork, Fiss, and Dworkin, each propounds a controversial ascount of the point of the enterprise of judicial decision-making (and specifieally constututional interpretation). Although the position of pure outsider can. in principle, be adopted, it leaves the theonst is ith litle to say. The reason philosophers are occupied with theories of law or morality or history but not with theories of baseball or chess is precisely because a theory of baseball would be uninteresting insofar as a would not pose controversial altematives with regard to the point of the prastice. A theorist of baseball would be a pure outsider, a pure describer. whereas a theorist of las or morality or history exists self-consciously in tension between commitment to a controversial justification of the prastice and transcendence of that commitment.

57. Supra n. 6. The analysis need not be limited to consututional deciston-mabing at to appellate dectstonmaking, but I do not try to generalize the argument here.

58. During the reign of logical positivism in the 1930's through the $1950 \mathrm{~s}$, morol. polttical. and legal phslosophy were in eclipse. Such then-popular theories as emotivism and preserputusm impled that moral and political discourse was not to be treated as a form of reasoning 50 muth as a form of pure 
uncover the constitutive rules ${ }^{59}$ of these practices. This way of understanding the relevant methodology was common to self-described legal positivists and legal naturalists. ${ }^{60} \mathrm{H}$. L. A. Hart described law as a complex game with two kinds of rules, those that instructed ordinary citizens on their obligations and rights and those that instructed officials in carrying forward institutional roles. To understand the task of judges is to understand the second-order rules that define their role.

The complexity of law as a practice becomes evident when we compare judges with the officials of real games. Ronald Dworkin reminds us that umpires in baseball exercise discretion in a different way from judges. ${ }^{61}$ Umpires are entrusted with the task of making final judgments about particular actions and events ${ }^{62}$ but the standards to be used are clearly and uncontroversially set for them. Even when umpires disagree about a result they do not and cannot disagree about the standards to be used in reaching the result. ${ }^{63}$ Judges, on the other hand, disagree about method as well as result.

Judges and umpires differ in yet another respect. Umpires are not in any sense players in a second-order game since groups of umpires do not characteristically engage in deliberative moves and countermoves. They make spontaneous and final decisions and the game moves on. Panels of judges on the other hand engage in complex practices of interaction that are observed and analyzed. One level of analysis is the informal level of social and political maneuvering that is largely unrecorded and invisible, more guessed about than seen. Another level is the explicit dialogue whereby written opinions, including dissenting opinions, spell out both results and justificatory strategies. Although it is rare for a particular case to elicit written opinions (concurrences, dissents) from several members of the panel, judges quickly become identified with particular strategies and their dialogue persists over series of related cases. Thus, the implicit dialogue becomes explicit.

The second-order practice of judging is therefore unlike the activity of umpires because it involves moves and countermoves among participants who are responding to each other's strategies and are aware of doing so. The relevant moves are justificatory arguments. (With regard to judging, as with other deliberative practices, one may have the illusion that the interactive character of the activity is inessential. It seems as if one can make judicial decisions or write history or make moral judgments without taking into account and responding to the judgments-legal, historical, moral-of others.

expression or attempted coercion. See, for example. J. Urmson. The Emotive Theory of Ethics (London: Hutchinson Press, 1968) and T. Weldon, The Vocabulary of Politics (Baltimore: Penguin, 1953). Hart's Concept of Law, supra n. 13, and Rawls' A Theory of Justice, supra n. 40, are the most influential masterworks in the renaissance of political and legal philosophy under the rubric of linguistic analysis.

59. Supra n. 46.

60. The distinction sketched by Rawls in "Two Concepts of Rules" was elaborated and used both by Hart in The Concept of Law and by Dworkin in the essays in Taking Rights Seriously, supra n. 4, 13, and 46.

61. Dworkin, Taking Rights Seriously,supra n, 4, pp. 31-39. Here Dworkin distinguishes among several senses of discretion.

62. E.g. actions such as whether player $x$ tagged up when he rounded second base, and events such as whether the ball was in the strike zone as it crossed home plate.

63. That is to say, they must abide by the rules of baseball as recorded and agreed-upon rules specifying what constitutes a strike, when a player must touch base, etc. The rules leave no effective room for ambiguity or interpretation. 
This illusion parallels the illusion that it is inessential for the recognition of color or pain that there be a public practice of labeling and distinguishing among colors, or of identifying and diagnosing pains, into which persons are initiated. As with color and pain, one's awareness of what counts as a move in forming a legal and moral judgment or in defending an account of history presumes an established context in which there are justificatory moves and countermoves. $)^{64}$

\section{b. The Limits of a Kuhnian Account of Judging}

Consider again the initial appeal of the metaphor of games as an idiom for the justificatory moves and countermoves of judging in general and constitutional interpretation in particular. The argument is straight-forward and exploits the comparison with color language. In describing color, we make sense and succeed in recognizing and communicating about color to the extent that we play by the same rules. What you call "red" is (more or less) ${ }^{65}$ what I call "red". If we were to play by different rules we would have, at best, only the appearance of mutual understanding and communication. In that case, we would either bring others round to our way of speaking, adopt their rules, or decline to engage further with them.

The discovery that judges are playing by different rules seems to produce an impasse and a crisis. The considerable and imaginative efforts of recent theorists fall readily into place as attempts to address what they see as an impasse. ${ }^{66}$ The impasse is explicable by noting two differences between the relatively simple game of color identification and the relatively complex one of judicial interpretation. The first difference is that discrepancies among players of the color game are immediately apparent. In the face of discrepancies, the game breaks down. Discrepant justificatory strategies among judges are less obvious. Decision making can proceed for some time under the public misconception that there are shared rules. The misconception may or may not be shared by the judges themselves.

The second difference explains the first. The practice of judging, unlike the practice of color identification, seems to call for a shared notion of the point of the activity which informs the rules governing reasoning and justification. ${ }^{67}$ This shared notion is what Thomas Kuhn, in the context of analyzing scientific theory-building, calls a "paradigm". Judges, like historians and those engaged in moral reasoning, have a favored conception of the purpose served by their activity. In true games, the goal of play is easily and unambiguously

64. Just as one can imagine a single judge sitting in judgment, one can also imagine a person alone in the desert identifying colors. But in both cases, the event is imaginable because it 15 also imaginable as a collective enterprise, whereby several persons carry out judgments, argue among themselves, ete. Compare Wittgenstein's observations on this, supra n. 26 and accompanying text.

65. Supra n. 27.

66. Most of the theorists of the late 1970's and early 1980's speak eloquently about a sense of ensts and an impasse with regard to theorizing about judging. See, for example, J. Ely. Democracy and Disirust (Cambridge, Mass: Harvard Univ. Press, 1980), at 73-75; L. Tribe, Constitutional Chatces (Cambridge, Mass: Harvard Univ. Press, 1985), at 3-21: and M. Perry. The Constiturion. The Caurts. and Humun Rights (New Haven: Yale Univ. Press, 1982), at 9-36.

67. Kuhn's account of scientific discovery and change is explained in T. Kuhn. The Structure of Sctenufic Revolutions (Chicago: Univ. of Chicago Press, 1962). See also I. Lakatos and A. Musgrave, Critrctsm and the Growth of Knowledge (Cambridgc: Cambridge University Press. 1970) and 1. Hacking. Scientific Revolutions (Oxford: Oxford Univ. Press, 1981). 
specified (checkmating the king, scoring the most runs). Kuhn argues that in shared activities of research and reasoning there must be a similar consensus, a shared understanding of the kind of knowledge sought and of the methods appropriate to seeking it. But in such activities as judging, and writing history, this shared understanding is problematic. Differing strategies of justification may be evidence, in Kuhn's terms, of differing paradigmatic understandings of the point of the activity.

This impasse yields a sense of crisis. Judges, unlike historians and individual moral agents, have a political role and wield institutional power. Any political actor becomes a threat to the security of the rule of law unless her power is constrained. Constraint for judges, in turn, seems to lie in the availability of a widely shared and uncontroversial conception of the purpose to be served by judges and of the rules for judging that flow from that conception. Some theorists prefer to say that such rules insure that judges will act objectively rather than subjectively. ${ }^{68}$ If, on the other hand, every conception is controversial among both judges and theorists, then judges are in fact unconstrained, loose and potentially destructive actors within the political structure. ${ }^{69}$

This analysis remains within the metaphor of games. Paradigm-driven activities are sophisticated games in several senses. The success of the activity depends on a shared conception of the purposes of the activity and of the rules to be followed. For Kuhn, of course, scientific research is the main example. In the light of his account, the game metaphor must be relaxed only slightly. It must be rethought to take account of the fact that the "game" of scientific investigation and reasoning does not proceed by discrete moves, does not begin and end at predetermined and rule-determined times, and is not competitive in a zero-sum sense (whereby a win by one player entails an equal loss by another).

The Kuhnian idea of an investigative paradigm - the idea of reasoning as a modified game-is the missing link between the simple idea of a game and the search for a theory of judicial interpretation. The effort of theorists is directed not toward simple assimilation with games but toward eliciting a shared idea of constitutional interpretation from which uncontroversial rules, as constraints and as ideals, follow. The alternatives that have received the most attention have long been familiar. Many writers favor adherence to the structure and role of government as conceived by the founders of the constitution. Such "interpretivism" takes two forms, adherence to the intentions of the founders insofar as it is discoverable through all kinds of historical investigation and adherence to the text of the constitution and to its original meaning. ${ }^{70}$ By contrast, other writers (noninterpretivists) look to the evolution of constitutional thought, in which the founders represent but one moment, and stress the continual rethinking of the role and structure of government

68. This notion of judicial objectivity is put forward by Owen Fiss in "Objectivity and Interpretation" (1982), 34 Stanford L. R. 739.

69. See sources listed, supra n. 66

70. Ely follows many other writers in adhering to the term "interpretivism." Tushnet and Brest, in their influential and persuasive critiques, prefer the term "originalism." See Tushnet, supra n. 8, and P. Brest, "The Misconceived Quest for the Original Understanding" (1980), 60 Boston University L. R. 204. See also R. Kay, "Adherence to the Original Intentions in Constitutional Adjudication: Three Objections and Responses" (1988), 82 Northwestern University L. R. 226. 
represented in our constitutional history. " Such theorists tend to see judges as spokespersons for a consensus of received values and ideals that may be loosely connected to the thought of the founders, uninformed as it is by the events of the last 200 years.

Theorists debate both the practicability and merits of such theories. Defenders of interpretivism must wrestle with the question whether the intentions of the founders are in fact retrievable in a way that dictates a discrete strategy of decision in hard cases. Defenders of non-interpretivism must wrestle with the equally intractable question whether any current and continuing social consensus exists about the issues raised by contemporary constitutional questions. Critics of both positions argue, often compellingly, that reference to original intent and reference to a pervasive social consensus mask the indiscipline of judges and that neither form of rhetoric proceeds from genuinely constraining rules. ${ }^{72}$

In the rest of this section, I shall address the question at a higher level of abstraction. If we grant that judges proceed and think of themselves as proceeding in all of the ways described by theorists, are we required by the metaphor of games and the Kuhnian requirement of a shared paradigm to admit that there is no shared practice, only the facade of one? How well indeed does the metaphor of games, as modified through Kuhn's model, really fit our deliberative practices?

\section{c. Judging as a Deliberative Practice}

The behavior of judges does not fit the metaphor of games. The simple metaphor of a game - with its discrete moves and static, written rules, with its clearly distinguished beginning and end-is clearly irrelevant. The more complex notion, the Kuhnian paradigm, is overtly metaphorical and says that communicative practices are game-like in an essential way-constituted by shared rules that define what counts as a move, what the point of communication is, and what counts as a relevant reason or relevant justificatory argument in discourse. Kuhn suggests that scientific investigation, like color identification, proceeds because we agree about what counts as a justificatory move, because we agree about what kinds of evidence are relevant in the process of making and debating judgments, and because we have a shared commitment to the point of the deliberative enterprise.

That's not how judges work. I have already looked at debates among historians, at moral discourse, and at judging, to suggest that in describing deliberative practices, even this more complex use of the game metaphor is unhelpful. According to the metaphor, the possibility of genuine deliberation presupposes common strategies of deliberation. Judges must have in common a conception of the point of the practice and of the rules of relevance that govern justificatory moves. The absence of shared rules is a defect; the more diverse the rules by which different participants operate, the more defective the practice is. The practice cannot proceed unless the defect is

71. Dworkin and Fiss are examples. Supra nn. 4 and 68.

72. Tushnet, among others, offers a compelling argument of this kind. Supra n. 8. 
cured. Judges who proceed in the face of such diversity re-enact the drama of Babel. By assumption, they cannot recognize each other's arguments as having justificatory force because they do not share the same assumptions about what counts as justification.

The actual practice of judges seems to fly in the face of this account. What this account describes as a defect is a definitive and inevitable feature of deliberation. Judges characteristically disagree not only about the results in particular cases but about the method through which results should be derived and defended. The distinction between interpretivists and non-interpretivists marks only the first layer of disagreement about method. Within the first (interpretivist) group, judges will differ about the level of generality with which the founders anticipated and set in motion a determinate structure and about the kinds of resources relevant to debates over their actions. Within the second (non-interpretivist) group, judges will differ in their conception of the kinds of goals and values appropriate to judicial (rather than, say, legislative) action and in their conception of the kinds of data-political, economic, sociological, psychological, historical - that are the "bottom line" of legal deliberation.

If such diversity seems ineradicable and if judicial deliberation (as constitutional interpretation) is characterized by such diversity, then the game metaphor is not a tool but an obstacle to understanding. The idea of a deliberative practice, as outlined in Section 2, is the alternative tool. A deliberative practice embraces participants with different commitments to different argumentative strategies and conceptions of goals. They are bound together not by shared rules but by mutual recognition of an array of relevant ways of proceeding. Deliberation proceeds as an activity in which each reaches and justifies judgments and deploys his justificatory strategy in part to persuade others to adopt it but also to vindicate his own way of making sense of experience.

This account explains an otherwise curious aspect of deliberative activity. A distinguishing feature of both games and Kuhnian game-like investigative paradigms is that implicit in each is a clear distinction between insiders and outsiders. In both games and game-like activities, the rules are settled during play. The role of an insider, a participant in the practice, is to make moves in accord with the rules and in the light of the mutually understood point of the practice. These moves may take the form of justificatory arguments in the case of scientific investigation for example. ${ }^{73}$ The role of an outsicler-an observer, commentator, or theorist-is to take note of the rules and illuminate them in the light of the implicit point of the practice. The outsider herself is not committed to the rules, is not in a position to make justificatory arguments, and must see the rules in some sense as an arbitrary posit. Thus the

73. This point illustrates the way in which the example of game-like activity, on the Kuhnian model, is midway between a real game and a deliberative practice. On the one hand is the requirement that participants must play by the same rules and must agree about the shared point or aim of their activity. In this sense, the model is a variant of a game. On the other hand the moves themselves are justificato. ry arguments, reasons for judgment. In this sense, the activity is like a deliberative practice. The distinction between insiders and outsiders (participants and theorists) is clearer in Kuhn's model than it is in a deliberative practice. 
outsider may contemplate the possibility of chess played, hypothetically, by different rules and the historical reality of scientific investigation proceeding under different paradigms. ${ }^{74}$

Deliberative practices do not yield so clear a distinction between the roles of insiders and outsiders. The so-called rules of the practice and the point served by them are inherently disputable. Justification within the practice means not merely justifying particular conclusions but particular ways of reaching those conclusions.

It may be said that the insider/outsider distinction can be transposed to deliberative practices with little modification. The outsider as theorist would thus have the role of describing the practice as a family of strategies of justification rather than as a single rule-governed strategy. But this may be too simple. A neutral or impartial standpoint is available to the outsider of a game because the point of a game is given and uncontroversial. The same is true of game-like investigative paradigms. But with deliberative practices like judicial reasoning, moral reasoning, or explaining history, the point of the enterprise is itself controversial. Even the outsider must, in this sense, choose sides.

Explaining why this is so requires a more general discussion of being inside and outside a practice. This, in turn, requires us to attend briefly to such abstract and intractable issues as the nature and limits of philosophy, and the nature and limits of self-awareness. Consider three steps in the development of these issues.

(1) A spontaneous general attitude toward knowledge and belief, ingrained both in ordinary attitudes and in the history of philosophy, is commonly called foundationalism. A foundationalist believes that all sorts of questions-about history, about the physical world, about psychology-have answers. Any issue is such that there is some truth about the matter, and the task of investigation is to discover that truth, to bring one's beliefs into accord with what is the case. This may be easy or difficult-easy if we wish to discover whether we are wearing shoes, difficult if we wish to discover the origin of the universe or the biography of an ancient prophet-but the task is to do what needs to be done to grasp what is true.

An insight of philosophers from Kant onward is that what we say we know about events, objects, persons, etc., is not simply the result of getting immediately in touch with how things "really are". What we know is conditioned by how we know, not only our physical capacities but also our conceptual frameworks. ${ }^{75}$ Wittgenstein and Kuhn in different ways draw conclusions from this insight. The ways in which we organize experience, ask questions about experience, and weigh evidence in drawing conclusions (forming beliefs, deciding what we know) are social practices, often widely shared

74. Critics of Kuhn question whether a theorist can indeed be an outsider in this sense or whether the reconstruction of scientific paradigms involves an implicit notton of ratuonaltty that transcends paradigms, a notion that allows us to speak meaningfully of progress in setence. See, for related issues, I. Lakatos, "History of Science and Its Rational Reconstruetuons". and $k$. Popper. "The Rationality of Scientific Revolutions", in Hacking. supra n. 67.

75. See general discussion of conceptual frameworks in D. Davidson. "On the Very ldea of a Conceptual Scheme", in Inquiries into Truth and Interpretation (Oxford: Oxford Lniv. Press. 1984): R. Rorty. Contingency Iromy and Solidarity (Cambridge: Cambridge Univ. Press, 1989): and H. Putnam. Reshsm and Reason, Philosophical Papers, volume 3 (Cambridge: Cambndge Unv. Press. 19831. 
but nonetheless variable over time.

(2) If no thinker can, in principle, extricate herself from her ways of knowing, from the social practices by which she has grown accustomed to organizing experience, then she can never claim that a particular way of knowing is privileged over others. Nor can she claim that one variant practice (one way of looking into history or thinking about the universe) gets closer than others to what is true.

Foundationalists must therefore yield to nonfoundationalists. The role of epistemology is not to show how it is that we are getting ever closer to the truth, getting from mediated knowledge to immediate knowledge, but to show how knowledge is mediated. ${ }^{76}$ The philosopher as epistemologist is the quintessential outsider with regard to the social practices of knowing. The insider is the inhabitant of the practice to whom the rules of the practice are second nature. Thus we come full circle to the metaphor of games in the sophisticated version suggested by Kuhn.

(3) It is necessary, in turn, to impeach this nonfoundationalist model and the metaphor on which it rests if we are to understand deliberative practices and specifically the practice of legal interpretation. The crucial point can be made in two interdependent ways. One is to say that deliberative practices do not involve (temporarily) settled ways of proceeding, within which reasoning and justification become possible, but competing ways of proceeding of which the various participants are aware. The other way of making the point is that the participants are simultaneously insiders and outsiders, insiders insofar as they are committed to a way of organizing experience that seems inescapable, outsiders insofar as they know that any justificatory move they can make is yet another move elaborating their own strategy within a deliberative practice.

In other words, deliberative practices do not permit theorists or practitioners to be outsiders in the nihilistic sense required by the metaphor of games. The foundationalist aspires to the possibility of being outside particular ways of thinking to apprehend reality in itself. The nonfoundationalist aspires to the possibility of being outside practices as games to achieve a point of indifference or neutrality toward all particular configurations of rules. Neither way of being outside is available vis-a-vis deliberative practices.

I am putting forward judicial interpretation-and whatever general understandings about law and legal systems follow from our understanding of judicial interpretation - as a clear example of a deliberative practice. I have been assuming that moral deliberation and debates about history yield other examples and that much of our reasoning activity has the character of a deliberative practice. But I shall leave aside any claims about just which kinds of reasoning fit the Kuhnian model and are in fact game-like and which, on the other hand, can be assimilated to judicial reasoning. ${ }^{77}$

76. One of the main ideas in Wittgenstein's On Certainty, supra n. 45, is that recognition that knowledge claims and claims about what is true can only occur within practices (or language-games) does not license skepticism or disenfranchise persons from using terms like "know" and "true." This recognition merely describes the conditions under which such terms are appropriately used. See Morawetz, supra n. 29 , chapters 4 and 5 .

77. No doubt some theorists would assimilate scientific investigation, Kuhn's main area of concern, with 
These distinctions help explain the failure of the most representative recent theories of constitutional interpretation. I shall use my critique of the metaphor of games and of the consequent distinction between insiders and outsiders to show how and why theorists have failed to appreciate that judicial interpretation is a deliberative practice.

\section{Theories of Constitutional Interpretation}

No overview can do justice to the rich literature on constitutional interpretation of the last fifteen years. My concern is not with the details of the debates but with their shared aims and motivations. The fear and goals of these theorists are grounded in the metaphor of a game gone awry. ${ }^{78}$ Their goal is to clarify and stabilize the rules of the game. This goal makes sense only as long as judicial interpretation is seen not as a deliberative practice but as a game. I shall suggest therefore that, at its most abstract level, the debate over constitutional interpretation is based on a misunderstanding of the kind of practice constitutional interpretation is and can be.

We have seen that we may simplify the matter by grouping theorists into three categories: interpretivists, noninterpretivists, and nihilists. ${ }^{79}$ Interpretivists and noninterpretivists are committed to the constructive goal implicit in the game metaphor, the goal of finding and defending constraining standards for judicial interpretation that may be regarded as the rules of the game. By "constraining" I mean three things. First, the standards define a method of justifying deliberative judgments so that judges may not do "whatever they wish". Second, the standards define a correct or distinctly preferable method of justifying deliberative judgments. Third, the standards are rigorous enough to produce answers to hard questions of judicial interpretation. Each of these three aspects of constraint needs explanation.

The first sense of constraint poses the alternatives of license and rule-following; either there are discoverable rules that define decisionmaking or there are none. If there are discoverable rules, they are the rules of the game, the same for all judges. The second sense of constraint implies that in the actual practice of judges one can discover several alternative (rule-like) ways of proceeding. Unless one can show that one way of proceeding is correct (or superior to others), the collection of alternatives is tantamount to license. In other words, there is no middle ground between license and univocal rules. Specifically, to say that judges do not have license because they may choose among a limited set of alternative constraining rules is nonsense. The third sense of constraint is addressed to the relationship between rules (or methods or ways of proceeding) and decisions. It says that if judges may properly choose among alternative ways of proceeding, the results of deliberation are not constrained, but if there is only one correct or superior way of proceeding,

a deliberative practice and would contest the existence of shared paradigms. Perhaps the best account of the matter would suggest that the two models are not mutually exclusive, and that some areas of investigation and deliberation come closer to one model while others approximate the other.

78. Supra text at $\mathrm{n} .49$ and passim.

79. These categories are explained above at text accompanying nn. 12-14, 70-71. and 81-83. 
then results are circumscribed. ${ }^{80}$

Nihilists agree that the goal of theory is to undercover a constraining theory, one that is constraining is all three senses. But they attempt to show that the goal cannot be achieved. After looking briefly at interpretive, noninterpretive, and nihilistic theory, I shall conclude by arguing that the underlying three-part notion of constraint is appropriate to an analysis of games but not to deliberative practices.

(1) Interpretivists are preoccupied with the first sense of constraint. They fear that judges will use the power of interpretation to effect political and social choices of their own. And they see the only adequate answer to that fear in the claim that concrete political and social choices have been taken out of the hands of judges $a b$ initio, i.e., by the drafters of the Constitution. They argue that unless the constitution-making process can be seen as anticipating and answering such questions with some specificity, constraint is a mirage.81

The underlying scheme of analysis for interpretivists rests on three assumptions.

(a) Judges either are constrained by shared rules or are not constrained. In the latter case they have license, may make up or vary the rules at will. ("Rules" in this context means "criteria for justificatory reasons".)

(b) For judges to be constrained by shared rules, they must have recourse to a decisional method that does not essentially require judgments about contemporary values, social and political evolution, or social needs. A method that bases decision making on these latter considerations allows judges recourse to a panoply of subjective opinions and is tantamount to license.

(c) On the other hand, structural and substantive determinations made by the authors and ratifiers of the Constitution anticipate answers to constitutional hard questions and the shared rules of decision making require deference to those determinations. The very idea of constitutionalism also mandates such deference.

The interpretive theory is both descriptive and normative. It claims to unpack the idea of decision making and to describe the rules that underlie the practice, properly understood. But in doing so, it describes a standard and an ideal. Also, most interpretivists would argue that their theory is doubly a theory of constraint. It strongly constrains the sort of resources appropriate to decision making. It also constrains results, but less strongly. ${ }^{82}$ Players playing

80. The relationship between rules and results is a complex one (not unlike the relationship between theories of metaethics and theories of substantive ethics). Practitioners who follow the same rules will not necessarily get the same results. The rules do not function as a decision procedure, nor do they put in place a deductive method. Rather, they are a criterion of relevance and importance for reasons. Historians who stress economic factors are more likely to attend to similar kinds of facts, but will not offer identical explanations. Judges who consult original intent will be disposed, one imagines, to entertain certain arguments about federalism but will not apply these arguments in the same way, nor will they necessarily come up with the same results in hard cases. The constraining effects of the rutes of a game like baseball or of an experimental process in, say, biochemical research also allow for differing ways of carrying out the activity-but one must not draw the analogy too closely.

81. Such assumptions seem to underpin the work of writers as diverse as Robert Bork, Richard Kay, and John Hart Ely. See, for example, R. Bork, "Neutral Principles and Some First Amendment Problems". (1971) 47 Indiana L. J. 1, and "The Impossibility of Finding Welfare Rights in the Constitution", (1979) Washington University L. Q. 695; R. Kay, supra n. 70; and J. Ely, supra n. 66.

82. Supra n. 80 . 
by the same rules will, nonetheless, play differently. Judges who attend to original intent may disagree about what the constitution requires in particular cases.

Beyond this, interpretivists vary in the details. Some proffer interpretivism reluctantly, as a measure of the limits on judicial power to benefit society. Others put it forth enthusiastically, as one component of a framework in which government interferes minimally in persons' lives. ${ }^{83}$ Some describe interpretivism as the only alternative to judicial license. Others claim only that it is a firmer constraint, a clearer rule, than others and defend it in the interest of institutional stability and predictability. ${ }^{\text {BA }}$

(2) Non-interpretivists accept the same first premise. They reject, however, the second premise.

$\left(b_{1}\right)$ Judges may be constrained by rules directing them to adhere to an evolved consensus about social value. Such rules may take various forms. According to various subtheories, judges may be required to reconstruct the abstract relationship between the individual and the state embodied in the Constitution, or they may be required to develop the best theory of constitutional rights that interprets concern and respect for individual autonomy, or they may be required to adhere to "disciplining rules" that insure fairness and conscientiousness in respecting shared values. ${ }^{\text {s. }}$

$\left(c_{1}\right)$ Adherence to such rules assures that judges will not decide in accord with whim, license, or personal preference. In other words they will decide objectively rather than subjectively. Such a procedure is in fact mandated by (or at least altogether consistent with) the Constitution, which anticipates that judicial interpretation will be shaped to the needs of the present rather than the dead hand of the past.

If the sticking point of interpretivism is that it may require judges to frustrate the best interests of the public in the interest of constitutionalism, the sticking point of noninterpretivism is that it presumes that the best interests will generally be transparent. The important point that I have emphasized throughout my analysis is that this expectation is unrealistic, not simply because judges have different "values" but because they have different ways of giving order to experience. What they share is mediated by language and the ways in which they differ are also reflected in language. The issue is not, as some political philosophers say, that some favor liberty and others equality. ${ }^{86}$ The issue is rather that the ways in which persons fit psychological, economic, political, social experiences together, the ways in which they make sense of their own lives and the lives of others, differ significantly and that hard questions of decision making fall prey to that diversity. The fact that some are libertarian and others egalitarian is merely a symptom of this more

83. This contrast is reflected. respectively. in the work of Richard Kay on the one hand and Robert Bork (and Edwin Meese) on the other.

84. In this instance, the former view is held by Bork (and perhaps by Ely I w hle the latter is held by Kay.

85. Arguably these views are held respectively by Thomas Grey, Owen Fiss, and Ronald Dusurkin. See, for example, T. Grey, "Do We Have an Unwritten Constitution?"” (1975). 27 Sistruerd L 8 703: O. Fiss. supra n. 68; and R. Dworkin, supra n. 4.

86. The tension between liberty and equality remains one of the prneipal conceptual ways in whtch alternative political theories are cast. It is possible to argue that this oppositusn is epuphenomenal and rests, in most cases, on deeper commitments to psychological, soetologteal. and methodological 
encompassing and greater diversity.

(3) The distinction between interpretivists and non-interpretivists, apparently so clear, depends on a naive epistemology. It presupposes that one can, at will, assume either of two cognitive positions. The first is a value-neutral self-transposition into the attitudes and opinions of historical actors. The other is an appropriation of the values of one's culture and one's political tradition. Both are distinguishable from the identification and deploying of one's own personal values. ${ }^{87}$

A special contribution of hermeneutics is to show how fragile and dubious these distinctions are. ${ }^{88}$ One's understanding of history is mediated through, and expressed within, the techniques of understanding - the categorical distinctions, the assumptions about value, etc.- that one employs as a particular participant in particular practices at a particular time in human history. Even if one can identify particular instances of tension between personal value preferences and a social consensus, or between a putative preference attributable to the founders and current attitudes, one cannot distinguish among these positions systematically. How one understands the past is colored by one's personal experiences. How one understands one's contemporaries affects one's decisions about values and goals.

The distinction between (b) and (b1) rests largely on a mistake about epistemology. The mistake is the following. Assume that one can distinguish (i) what the founders would have said about situation $\mathrm{x}$, (ii) what a contemporary social consensus would maintain about situation $x$, and (iii) how Judge $J$ would prefer to resolve situation $x$. To distinguish these conceptually is not the same as saying that judges either do or can follow one of the three methods of decision to the exclusion of the others. Indeed any judge's particular way of deciding will be affected by all three kinds of considerations. All three kinds affect each other in ways that only the foolhardy would claim to disentangle.

Equally foolhardy is the epistemological assumption that a judge can choose the perspective from which to decide a case. The particular way in which these three kinds of consideration color a judge's way of proceeding is neither volitional nor optional, no more volitional than the capacity to find a melody in a song or to notice a logical inconsistency or to avoid an on-coming truck in driving. All are aspects of participating in practices and all, while subject to reflection and conditioned by learning, are spontaneous responses to situations. ${ }^{89}$

The flaw, therefore, in much constitutional theory is represented by

assumptions made by the theorists who deploy various views about the relationship between liberty and equality. See, for example, A. Ryan, The Idea of Freedom: Essays in Honour of Isaiah Berlin (Oxford: Oxford University Press, 1979); A. Gutmann, Liberal Equality (Cambridge: Cambridge University Press, 1980); and S.M. McMurrin, Liberty, Equality, and the Law: Selected Tanner Lectures on Moral Philosophy (Salt Lake City: Univ. of Utah Press, 1987).

87. To be sure, the interpretivist rejects the distinction between the second and third of these stances, while the noninterpretivist defends it.

88. See D. Hoy, "Interpreting the Law: Hermeneutical and Poststructuralist Perspectives", (1985) 58 Southern California L. R. 135; T. Grey, "The Hermeneutics File" (1985), 58 Southern California L. R. 221; H-G. Gadamer, supra n. 20.

89. The last few paragraphs are to be taken as phenomenological and hermeneutical description. It is not clear to me how, other than through appeal to intuition, any theorist would "prove" these observations. 
assumption (a). Judges are indeed constrained, but not by shared rules. They are constrained individually by a particular way of addressing and understanding interpretive questions and they are constrained collectively by the fact that the shared practice embraces a limited range of ways of proceeding. This limitation is mutually understood and recognized.

The idea that there must be a single set of shared rules, or license in the alternative, is dictated by the assumption that practices are like games. This paradigm, which may ${ }^{90}$ work (as Kuhn suggests it does) for scientific investigation with its emphasis on progress and experimental manipulation of data to confirm or disconfirm hypotheses, works badly and distortingly when applied to deliberative practices, such as constitutional interpretation. But the assumption that license is the only alternative to shared rules runs deep in constitutional theory.

\section{Conclusion}

Wittgenstein says that philosophy describes our practices but does not change them. ${ }^{11}$ Some have argued that the metaphor of games is well adapted to describing our practices, because it points us in the direction of eliciting and investigating the shared rules that characterize practices, rather than changing them. But the metaphor itself is coercive. Our more complex deliberative practices do not fit the simplicity of the metaphor and the attempt to find shared rules becomes, inevitably, a summons to change the practice, to harmonize the several ways of proceeding under a single paradigm. To heed this suggestion is to distort the phenomenon that one seeks to describe. Judges disagree, not only in results but in the ways in which they arrive at those results. It is not within the compass of jurisprudence to change this, nor is it within its power.

90. Supra n. 77.

91. Supra n. 42. 
